\title{
PEMBAHARUAN SANKSI PAJAK SEBAGAI UPAYA MENGOPTIMALKAN PENERIMAAN NEGARA
}

\author{
Amelia Cahyadini, \\ Fakultas Hukum, Universitas Padjadjaran \\ email: amelia.cahyadini@unpad.ac.id \\ Budi Arta Atmaja \\ Fakultas Hukum, Universitas Padjadjaran \\ email: budiartmaja@gmail.com \\ Indra Oka Margana \\ Fakultas Hukum, Universitas Padjadjaran \\ email: indraoka.law@gmail.com
}

disampaikan 29/11/17 - di-review 29/11/17 - diterima 25/12/17

DOI: $10.25123 /$ vej.2776

\begin{abstract}
This paper discusses the imposition of penal-administrative sanctions to recalcitrant tax payers. Stress shall be given to the importance of legal (penal-administrative) sanctions as deterrence factor and a way to increase state earning from tax. A critical analysis shall be performed to the existing general rules and sanction mechanism as found in Law No. 20 of 2007 (general rules and procedures of taxation). Special attention shall be given to trade off made by the Prosecutor Office, on the basis of a request from the Ministry of Finance, i.e. cessation of on-going criminal investigation in return of tax payer agree to pay full amount of tax due plus punitive administrative sanction: four times the full amount due. On the basis of this critical analysis the author suggests a number of improvements to be made.
\end{abstract}

Keywords:

tax sanctions; cessation of criminal investigation; tax penal-administrative-social-sanction.

\begin{abstract}
Abstrak
Tulisan ini menelaah penjatuhan sanksi terhadap pelaku tindak pidana pajak. Pentingnya sanksi di bidang hukum pajak adalah sebagai pencegahan upaya penghindaran pengenaan pajak dan mendorong penerimaan Negara dari pajak. Telaah kritis akan diberikan pada ketentuan umum dan mekanisme penjatuhan sanksi pada wajib pajak berdasarkan Undang-Undang No. 28 tahun 2007 (ketentuan umum dan tata cara perpajakan). Perhatian khusus akan diberikan pada kesepakatan untuk menghentikan penyidikan (oleh jaksa agung atas permintaan menteri keuangan) dengan syarat wajib pajak membayar lunas nilai pajak terhutang ditambah denda administratif sejumlah empat kali nilai pajak terhutang. Berdasarkan telaahan itu penulis akan menawarkan beberapa gagasan perbaikan dan pengembangan bagi penjatuhan sanksi yang mampu memenuhi rasa keadilan masyarakat.
\end{abstract}

Kata kunci:

pidana pajak; penghentian penyidikan; sanksi administratif pajak; sanksi sosial pajak; sanksi pidana pajak. 


\section{Pendahuluan}

Salah satu sumber penerimaan Negara Indonesia dalam Anggaran Pendapatan dan Belanja Negara (selanjutnya disebut APBN) adalah berasal dari sektor pajak. Pajak menyumbang sekitar 75 \% dari seluruh penerimaan negara. ${ }^{1}$ Penerimaan negara dari sektor pajak terus meningkat setiap tahunnya, sebagaimana terdapat dalam tabel di bawah ini: ${ }^{2}$

\begin{tabular}{cccc}
\hline Tahun & $\begin{array}{c}\text { Pendapatan Negara } \\
\text { (dalam Triliun } \\
\text { Rupiah) }\end{array}$ & $\begin{array}{c}\text { Pendapatan Negara dari } \\
\text { Pajak (dalam Triliun } \\
\text { Rupiah) }\end{array}$ & $\begin{array}{c}\text { Persentase } \\
\text { Pendapatan Negara } \\
\text { dari Pajak }\end{array}$ \\
\hline 2010 & 995,3 & 628,2 & $63,1 \%$ \\
\hline 2011 & $1.210,6$ & 742,7 & $61,3 \%$ \\
\hline 2012 & $1.338,1$ & 835,8 & $62,5 \%$ \\
\hline 2013 & $1.438,9$ & 921,4 & $64,0 \%$ \\
\hline 2014 & $1.550,6$ & 985,1 & $63,5 \%$ \\
\hline APBNP 2015 & $1.761,6$ & $1.294,3$ & $73,5 \%$ \\
\hline APBN 2016 & $1.822,5$ & $1.546,7$ & $75 \%$ \\
\hline
\end{tabular}

Pemungutan pajak merupakan salah satu bentuk kemandirian suatu negara untuk membiayai segala keperluan serta pembangunan dengan cara menggali sumber daya yang berasal dari dalam negeri. Untuk mewujudkan kemandirian pembiayaan ini diperlukan peran serta masyarakat dalam membiayai pembiayaan nasional yaitu dengan melakukan kewajibannya dalam membayar pajak sebagai sumber penerimaan negara. ${ }^{3}$ Untuk itu diperlukan kesadaran dan kepatuhan masyarakat dalam upaya mengoptimalkan semua potensi dan sumber daya yang ada.

Sistem pemungutan pajak di Indonesia adalah sistem yang memberi wewenang kepada wajib pajak untuk menghitung, memperhitungkan, membayar, dan melaporkan sendiri besarnya pajak yang terutang, ${ }^{4}$ atau dikenal dengan

1 Direktorat Penyusunan APBN, Direktorat Jenderal Anggaran, Informasi APBN 2016, https://www.kemenkeu.go.id/sites/default/files/bibfinal.pdf (terakhir diakses 1 September 2017).

2 Id.

3 Zainal Muttaqin, dkk, Penegakan Hukum di Bidang Perpajakan Melalui Mekanisme Diluar Pengadilan (Suatu Alternatif), Jurnal Mimbar Hukum Universitas Gadjah Mada Vol. 27 No. 2, Juni 2015, hlm 2.

4 Syofrin Syofyan dan Asyhar Hidayat, Hukum Pajak dan Permasalahannya, Refika Aditama, Bandung, 2004, hlm. 16. 
sistem self assessment sebagaimana tercantum dalam Pasal 12 ayat (1) dan (2) Undang-Undang Nomor 6 Tahun 1983 tentang Ketentuan Umum dan Tata Cara Perpajakan sebagaimana telah diubah terakhir dengan Undang-Undang Nomor 16 Tahun 2009 (selanjutnya disebut Undang-Undang KUP).

Wajib pajak harus aktif menghitung dan melaporkan jumlah pajak terutangnya tanpa campur tangan fiskus. Konsekuensi dijalankannya sistem self assessment adalah bahwa masyarakat harus benar-benar mengetahui tata cara menghitung pajak dan segala sesuatu yang berhubungan dengan pelunasan pajaknya. Selain itu, berdasarkan sistem self assessment, sepanjang Direktorat Jenderal Pajak tidak memiliki data dan informasi yang bertentangan atau tidak sesuai dengan data yang diberikan wajib pajak, maka data yang diberikan wajib pajak dianggap benar. ${ }^{5}$

Dalam rangka pengawasan kepatuhan pelaksanaan kewajiban perpajakan sebagaimana konsekuensi penerapan sistem self assessment, data dan informasi yang berkaitan dengan perpajakan yang bersumber dari instansi pemerintah, lembaga, asosiasi, dan pihak lain sangat diperlukan oleh Direktorat Jenderal Pajak. Data dan informasi dimaksud adalah data dan informasi orang pribadi atau badan yang dapat menggambarkan kegiatan atau usaha, peredaran usaha, penghasilan dan/atau kekayaan yang bersangkutan, termasuk informasi mengenai nasabah debitur, data transaksi keuangan dan lalu lintas devisa, kartu kredit, serta laporan keuangan dan/atau laporan kegiatan usaha yang disampaikan kepada instansi lain di luar Direktorat Jenderal Pajak.

Data dan informasi yang berkaitan dengan perpajakan yang diberikan oleh instansi pemerintah, lembaga, asosiasi, dan pihak lain belum mencukupi, untuk kepentingan penerimaan negara, Direktur Jenderal Pajak dapat menghimpun data dan informasi yang berkaitan dengan perpajakan sehubungan dengan terjadinya suatu peristiwa yang diperkirakan berkaitan dengan pemenuhan kewajiban perpajakan wajib pajak dengan memperhatikan ketentuan tentang kerahasiaan atas data dan informasi dimaksud.

\footnotetext{
${ }^{5}$ Hasil wawancara dengan Eri Dripa, Kepala Kantor Pajak Pratama Kramat Jati, Jalan Dewi Sartika Nomor 189 A, Jakarta Timur, pada Jumat, 11 April 2014, jam $09.00-10.30$.
} 
Berkaitan dengan pengawasan yang dilakukan oleh Direktorat Jenderal Pajak, pengawasan dilakukan dengan meneliti setoran wajib pajak, baik setoran dari wajib pajak perorangan maupun setoran dari wajib pajak badan yang telah disetorkan kepada kas negara. ${ }^{6}$ Pengawasan tersebut berupa menelaah jumlah yang telah disetorkan oleh wajib pajak apakah jumlah tersebut sesuai dengan kewajiban yang dilunasinya. Kegiatan pengawasan ini berkaitan dengan ketersediaan data wajib pajak dan kepemilikan NPWP.

Terhadap wajib pajak yang diketahui melakukan pelanggaran dan kejahatan dalam perpajakan, undang-undang perpajakan telah memberikan ancaman sanksi administrasi dan sanksi pidana. Sanksi administrasi menurut Undang-Undang KUP terbagi menjadi tiga jenis, yaitu denda, bunga, dan kenaikan. Sementara itu mengenai sanksi pidana, dalam Undang-Undang KUP telah ditetapkan perbuatan wajib pajak, fiskus (Petugas/Pegawai/Pejabat/Aparat Perpajakan) dan pihak ketiga (Bank, Notaris, Konsultan Pajak, Akuntan Publik, Kantor Administrasi) yang dapat diancam dengan sanksi pidana pada Pasal 38 sampai Pasal 43. Pada tulisan ini Penulis menitikberatkan pada perbuatan pidana pajak yang dilakukan oleh wajib pajak. Perbuatan wajib pajak yang diancam pidana dalam Pasal 38 dan Pasal 39 Undang-Undang KUP meliputi perbuatan yang berkenaan dengan surat pemberitahuan (SPT), penyalahgunaan Nomor Pokok Wajib Pajak (NPWP), penyampaian data yang tidak benar, tidak menyetor pajak, dan tidak membayar pajak. ${ }^{7}$

Hingga saat ini belum ada data yang pasti berapa jumlah wajib pajak yang diproses ke pengadilan karena melakukan tindak pidana di bidang pajak, akan tetapi hal ini dapat dilihat dari beberapa hal, salah satunya rasio pajak di Indonesia. Sebagaimana diketahui, rasio pajak dipengaruhi beberapa faktor, diantaranya tarif pajak, tingkat pendapatan per kapita dan tingkat optimalisasi tata laksana pemerintahan yang baik, sebagai faktor makro, dan tingkat kepatuhan Wajib Pajak, komitmen dan koordinasi antar-lembaga negara serta kesamaan

\footnotetext{
${ }^{6}$ Bohari, Pengantar Singkat Hukum Pajak, 18 (PT. Rajawali Persada, Jakarta, 1995).

7 Rochmat Soemitro, Asas dan Dasar Perpajakan, 22 (PT Eresco, Bandung, 1993).
} 
persepsi antara Wajib Pajak dan petugas pajak, sebagai faktor mikro. ${ }^{8}$ Rasio pajak hingga saat ini menjadi ukuran yang dianggap memberi gambaran umum atas kondisi perpajakan di suatu negara. Rasio pajak di Indonesia tahun 2017 adalah $11 \%$, rasio ini merupakan rasio terendah di dunia. ${ }^{9}$

Berdasarkan data yang terdapat dalam Destination Statement Direktorat Jenderal Pajak Tahun 2015-2019, diketahui bahwa jumlah wajib pajak terdaftar hingga tahun 2017 adalah sebanyak 40 juta, ${ }^{10}$ sementara yang melaporkan SPT hingga tahun 2016 adalah 9,01 juta wajib pajak, atau sebesar 54,54\% dari jumlah wajib pajak yang wajib lapor SPT sebesar 16,5 juta wajib pajak. ${ }^{11}$ Berdasarkan hal tersebut, secara hipotesis jika dihubungkan dengan adagium bahwa setiap orang mempunyai kecenderungan untuk menghindari pajak, maka akan banyak wajib pajak terkena sanksi pidana sebagaimana diatur dalam Pasal 38 dan Pasal 39.12

Berdasarkan hal tersebut, maka penegakan hukum yang dilakukan khususnya dalam tindak pidana di bidang perpajakan merupakan hal penting dalam rangka memenuhi rasa keadilan di masyarakat dan kepastian hukum itu sendiri. Namun sebagaimana diketahui bahwa regulasi terkait dengan tindak pidana dalam bidang perpajakan tersebut merupakan ultimum remedium (upaya terakhir) ketika sanksi administrasi yang menjadi sanksi utama dianggap tidak dapat memberikan sanksi yang cukup terhadap Wajib Pajak yang terbukti melakukan Kealpaan, Pelanggaran atau Kejahatan di bidang pajak. Alasan diutamakannya pemberian sanksi secara administrasi tersebut terkait dengan upaya pemulihan penerimaan negara.

\footnotetext{
8 Admistrator, Apa Itu Tax Ratio?, https://solusibisnis.co.id/apa-itu-tax-ratio-rasio-pajak.html (terakhir diakses 10 Oktober 2017).

9 Gito Adiputo Wiratno, Sri Mulyani: Tax Ratio Indonesia Terendah, https://www.wartaekonomi.co.id/read126937/sri-mulyani-tax-ratio-indonesia-terendah.html (terakhir diakses 3 November 2017).

10 Direktorat Jenderal Pajak, Laporan Kinerja Direktorat Jenderal Pajak 2016, http://www.pajak.go.id/sites/default/files/LAKIN\%20DJP\%202016.pdf (terakhir diakses 7 Agustus 2017).

11 Safyra Primadhyta, Wajib Pajak Yang Lapor SPT Tembus 9,01 Juta Orang, https://www.cnnindonesia.com/ekonomi/20170402035743-78-204324/wajib-pajak-yanglapor-spt-tembus-9-juta-orang/ (terakhir diakses 17 Agustus 2017).

12 Zainal Muttaqin dkk, supra catatan no. 6, pada 4.
} 
Dalam proses penyidikan terkait pidana perpajakan terdapat hal yang menarik terkait dengan pasal 44B Undang-Undang KUP yang menyatakan, untuk kepentingan penerimaan negara, Jaksa Agung atas permintaan Menteri Keuangan dapat menghentikan penyidikan apabila wajib pajak telah melunasi utang pajak yang tidak atau kurang dibayar dengan ditambah sanksi administrasi berupa denda sebesar empat kali jumlah pajak yang tidak atau kurang dibayar.

Penghentian penyidikan atas permintaan menteri keuangan kepada jaksa agung dilakukan dengan maksud tidak semata-mata bertujuan untuk memberikan sanksi pidana seperti pada umumnya diberikan pada pelaku tindak pidana, namun bagaimana agar masyarakat memahami ketentuan undang-undang perpajakan dalam rangka mengoptimalkan penerimaan negara. ${ }^{13}$ Tujuan hukum pajak pada prinsipnya adalah bukan untuk mempidana wajib pajak tetapi bagaimana agar uang pajak dapat direalisasikan sebagai sumber penerimaan negara. ${ }^{14}$ Dalam hal ini hukum pajak lebih berorientasi kepada asas kemanfaatan bagi kepentingan penerimaan negara, bukan untuk memidana. ${ }^{15}$ Namun yang perlu mendapat perhatian adalah apakah ketentuan tersebut efektif.

Penghentian penyidikan yang didasarkan pada ketentuan Pasal 44B Undang-Undang KUP dapat saja dinilai positif jika dilihat dari sisi penerimaan negara, berdasarkan filosofis hukum pajak. Akan tetapi penghentian dimaksud dapat juga dinilai tidak efektif dari sisi kepastian hukum yang seharusnya diteruskan proses penyelesaiannya di tingkat penuntutan dan persidangan. Pertanyaan yang selanjutnya yang timbul adalah dimana letak kepastian hukumnya apabila semua tindak pidana pajak dapat digantikan dengan sejumlah uang tanpa penyelesaian proses tindak pidana? Lalu mengapa untuk kasus yang terkait dengan keuangan negara tidak diberlakukan proses hukum yang sama?16 Sebagaimana asas ultimum remedium, yaitu pengenaan sanksi pidana merupakan upaya terakhir, maka ketika telah dilakukan upaya terakhir tersebut, seharusnya

\footnotetext{
13 Rochim, Modus Operandi Tindak Pidana Pajak, Solusi Publishing, Jakarta, 2010, hlm. 24. 14 Id. $15 \mathrm{Id}$.

16 Wirawan B. Ilyas dan Richard Burton, Manajemen Sengketa dalam Pemungutan Pajak Analisis Yuridis Terhadap Teori dan Kasus, Mitra Wacana Media, Jakarta, 2012, hlm. 137-138
} 
dilaksanakan sampai selesai, dalam artian sampai dilakukannya penuntutan ke pengadilan lalu mendapat putusan hakim.

Sehingga penulis dalam tulisan ini akan membahas bagaimana kedudukan sanksi pidana dalam perkara pajak sebagai upaya mengoptimalkan pemulihan penerimaan negara untuk mewujudkan kesejahteraan? Dalam tulisan ini penulis membahas mengenai pajak dalam perekonomian Indonesia, sanksi dalam perpajakan di Indonesia, dan konsep pemulihan penerimaan negara dari tindak pidana bidang perpajakan.

\section{Pembahasan}

\section{Pajak dalam Perekonomian Indonesia}

Pajak pada hakikanya mengenai hidup negara secara ekonomis, demikian pula pajak merupakan sumber pendapatan utama negara di samping sumber daya alam. ${ }^{17}$ Jacobsen dan Lipman mengemukakan mengenai tujuan dan fungsi negara, bahwa suatu sistem pemungutan pajak merupakan fungsi esensil dari negara, yaitu fungsi yang diperlukan demi kelanjutan atau kelangsungan hidup negara. ${ }^{18}$ Membayar pajak bukan hanya merupakan kewajiban, tetapi merupakan hak dari setiap warga negara untuk ikut berpartisipasi dalam bentuk peran serta terhadap pembiayaan negara dan pembangunan nasional. ${ }^{19}$

Pajak adalah kontribusi wajib kepada negara yang terutang oleh orang pribadi atau badan yang bersifat memaksa berdasarkan Undang-Undang, dengan tidak mendapatkan imbalan secara langsung dan digunakan untuk keperluan negara bagi sebesar-besarnya kemakmuran rakyat. ${ }^{20}$ Terdapat beberapa pendapat dari para sarjana mengenai pengertian pajak. Pajak dapat didekati dari berbagai sudut ilmu dan cara pendekatan yang berbeda sehingga mengakibatkan timbulnya

\footnotetext{
17 Dadang Yusuf Juhaeni, Pengaturan Pemungutan dan Pengawasan Pajak Pada Transaksi Melalui Elektronic Commerce (E-Commerce) Guna Meningkatkan Penerimaan Negara, Tesis Magister Kenotariatan Pascasarjana Universitas Padjadjaran, Bandung, 2011, hlm. 13 (tidak dipublikasi).

18 G.A. Jacobsen dan M.H. Lipman, Political Science, College Outline Series, 17 (Barnes \& Noble Inc, New York, 1960).

${ }^{19}$ Administrator, Belajar Pajak, www.pajak.go.id, (terakhir diakses 29 Oktober 2012).

20 Undang-Undang Nomor 28 tahun 2007 tentang Perubahan Ketiga Atas Undang-Undang Nomor 6 Tahun 1983 Tentang Ketentuan Umum Dan Tata Cara Perpajakan Pasal 1 angka 1.
} 
pengertian pajak yang berlainan. ${ }^{21}$ Pendekatan pajak dari segi ekonomi menimbulkan pengertian pajak yang menitikberatkan pada segi ekonomi, misalnya definisi yang dikemukakan oleh Soeparman Soemahamidjaja, yaitu pajak adalah iuran wajib, berupa uang atau barang yang dipungut oleh penguasa berdasarkan norma-norma hukum, guna menutup biaya produksi barang-barang dan jasa kolektif dalam mencapai kesejahteraan umum. ${ }^{22}$

Pajak dari segi hukum dapat didefinisikan sebagai perikatan yang timbul karena undang-undang yang mewajibkan seseorang yang memenuhi syarat-syarat yang telah ditentukan oleh undang-undang (tatbestand) untuk membayar sejumlah uang kepada kas negara, yang dapat dipaksakan, tanpa mendapatkan suatu imbalan yang secara langsung dapat ditunjuk, yang digunakan untuk membiayai pengeluaran-pengeluaran negara (rutin dan pembangunan) dan digunakan sebagai alat (pendorong, penghambat) untuk mencapai tujuan di luar bidang keuangan. ${ }^{23}$ Prestasi yang dilakukan oleh subjek pajak untuk membayar pajak tidak mendapat imbalan langsung yang dapat ditunjukkan. ${ }^{24}$

Dikaitkan dengan prinsip kedaulatan rakyat dan Negara Indonesia adalah negara hukum, ${ }^{25}$ serta kewenangan DPR untuk membentuk undang-undang, ${ }^{26}$ maka akan dihasilkan konsep bahwa ketentuan-ketentuan tersebut memberi landasan yuridis dalam pemungutan pajak yang harus didasari persetujuan dari rakyat sebagai pemilik kedaulatan yang mekanisme pelaksanaannya didasari Undang-Undang Dasar 1945 yakni bahwa dalam pembentukan undang-undang pajak, peran DPR sebagai pihak yang mewakili rakyat sangat menentukan. Sehingga undang-undang pajak tersebut bukan semata-mata lahir dari keinginan pemerintah untuk mendapatkan penerimaan negara melainkan bahwa rakyat setuju untuk dipunguti pajak dalam rangka berpartisipasi membiayai

\footnotetext{
${ }^{21}$ Dewi Kania Sugiharti, Perkembangan Peradilan Pajak di Indonesia, Refika Aditama, Bandung, 2005, hlm. 2.

22 Santoso Brotodihardjo, Pengantar Ilmu Hukum Pajak, Refika Aditama, Bandung,. 1998, hlm 4.

${ }^{23}$ Rochmat Soemitro, Pengantar Singkat Hukum Pajak, Eresco, Bandung, 1992, hlm. 13.

24 Bohari, supra catatan no. 9, hlm. 23.

25 Undang-Undang Dasar Negara Republik Indonesia Tahun 1945 Pasal 20 ayat (2) dan (3).

26 Undang-Undang Dasar Negara Republik Indonesia Tahun 1945 Pasal 20 ayat (1).
} 
pengeluaran-pengeluaran negara demi kelangsungan hidup bangsa dan negaranya. ${ }^{27}$

Berdasarkan ketentuan tersebut maka Dewan Perwakilan Rakyat membuat dan menetapkan undang-undang perpajakan bagi Negara Kesatuan Republik Indonesia. Kewenangan pemerintah dalam menarik pajak dibatasi oleh ketentuan dalam Undang-Undang dan Undang-Undang Dasar 1945. ${ }^{28}$ Dengan demikian maka pada prinsipnya negara memiliki wewenang untuk menagih pajak kepada wajib pajak, dimana dalam prosesnya dapat dipaksakan karena telah diatur dalam bentuk Undang-Undang. Konsekuensi hukum tersebut adalah pengenaan sanksisanksi perpajakan. Pengenaan sanksi perpajakan memiliki tujuan untuk menciptakan kepatuhan wajib pajak dalam melaksanakan kewajibannya. Sanksi perpajakan dapat dikatakan merupakan alat pencegah (preventif) agar wajib pajak tidak melanggar norma pajak. ${ }^{29}$

Tidak dapat dipungkiri bahwa penerimaan negara dari sektor pajak dapat dikatakan sebagai satu-satunya sumber penerimaan negara yang dapat diandalkan untuk mengisi keuangan negara yang disebutkan dalam APBN berdasarkan data yang telah diuraikan sebelumnya pada pendahuluan. Berdasarkan data tersebut diketahui bahwa penerimaan dari pajak mendominasi penerimaan negara, artinya pajak menjadi unsur yang sangat menentukan keberhasilan dan keberlangsungan pembangunan untuk kesejahteraan seluruh rakyat Indonesia dan digunakan untuk membiayai berbagai macam penyelenggaraa pemerintahan dan pembangunan. Oleh karena itu, ketika pemerintah secara terus menerus menyuarakan pentingnya kesadaran masyarakat membayar pajak maka masyarakat sudah seharusnya memberikan dukungan nyata dengan membayar pajak sesuai aturan perundang-undangan.

\footnotetext{
27 Dewi Kania Sugiharti, Prospek Pengaturan Insentif dan Disinsentif Pajak berkaitan dengan Penerapan Prinsip Pencemar Membayar Sebagai Perwujudan Sistem Hukum Nasional, Disertasi, Fakultas Hukum Universitas Padjadjaran, Bandung, 2010, hlm. 102-103, (tidak dipublikasi). ${ }^{28}$ Rochmat Soemitro, Hukum Pajak Internasional Indonesia Perkembangan dan Pengaruhnya, Eresco, Bandung, 1977, hlm. 30.

${ }^{29}$ Mardiasmo, Perpajakan Edisi Revisi 2011, Andi, Yogyakarta, 2011, hlm 59.
} 


\section{Sanksi dalam Perpajakan di Indonesia}

Sanksi dalam perpajakan terbagi dua, yaitu sanksi administrasi dan sanksi pidana. Sanksi administrasi mencakup bunga, kenaikan, dan denda. Sedangkan sanksi pidana mencakup pidana penjara, kurungan, dan denda pidana. Dalam konteks pidana yang berhubungan dengan pajak, yang dimaksud dengan pidana perpajakan adalah informasi yang tidak benar mengenai laporan yang terkait dengan pemungutan pajak dengan menyampaikan surat pemberitahuan, tetapi yang isinya tidak benar atau tidak lengkap atau melampirkan keterangan yang tidak benar sehingga dapat menimbulkan kerugian pada negara dan kejahatan lain yang diatur dalam undang-undang yang mengatur perpajakan. ${ }^{30}$ Ada atau tidaknya tindak pidana dalam perpajakan dimulai dengan dilakukannya pemeriksaan oleh Dirjen Pajak yang kemudian apabila ditemukan adanya bentuk kealpaan, pelanggaran atau kejahatan terhadap pajak itu sendiri, maka akan dilakukanlah proses pemberian sanksi secara administrasi. Kemudian apabila ternyata pemberian sanksi administrasi tersebut dianggap tidak cukup atau wajib pajak menolak melaksanakan sanksi administrasi tersebut, maka dilakukanlah upaya terakhir yaitu sanksi pidana.

Proses pertamanya adalah penyidikan. Dimana penyidikan ini dilakukan oleh pejabat pegawai negeri sipil yang di beri wewenang khusus oleh UndangUndang untuk melakukan penyidikan,31 dalam hal ini adalah penyidik pajak. Penyidikan tindak pidana di bidang perpajakan adalah serangkaian tindakan yang dilakukan oleh Penyidik untuk mencari serta mengumpulkan bukti yang dengan bukti itu membuat terang tindak pidana di bidang perpajakan yang terjadi serta menemukan tersangkanya. ${ }^{32}$ Penyidikan tindak pidana di bidang perpajakan hanya dapat dilakukan oleh Pejabat Pegawai Negeri Sipil tertentu di lingkungan

\footnotetext{
30 Undang-Undang Nomor 25 tahun 2007 tentang Penanaman Modal Penjelasan Pasal 33 ayat (3).

${ }^{31}$ Kitab Undang-Undang Hukum Acara Pidana Pasal 1 angka 1.

32 Undang-Undang Nomor 28 tahun 2007 tentang Perubahan Ketiga Atas Undang-Undang Nomor 6 Tahun 1983 Tentang Ketentuan Umum Dan Tata Cara Perpajakan Pasal 1 angka 31.
} 
Direktorat Jenderal Pajak yang diberi wewenang khusus sebagai penyidik tindak pidana di bidang perpajakan. ${ }^{33}$

Kualifikasi perbuatan wajib pajak yang dapat dijatuhi sanksi administrasi atau pidana dapat dilihat dalam Pasal 38 dan Pasal 39 Undang-Undang KUP. Pasal 38 Undang-Undang KUP menyebutkan bahwa pelanggaran terhadap kewajiban perpajakan yang dilakukan oleh wajib pajak sepanjang menyangkut tindakan administrasi perpajakan dikenakan sanksi administrasi. Pada kenyataan, seseorang dikatakan telah melakukan tindak pidana perpajakan apabila telah dilakukan pemeriksaan terlebih dahulu oleh pemeriksa pajak dan diperoleh buktibukti bahwa wajib pajak benar melakukan tindak pidana sebagaimana dimaksud Pasal 38 Undang-Undang KUP yang memuat unsur subjektif berupa karena keaalpaan. Unsur objektifnya adalah tidak menyampaikan surat pemberitahuan atau menyampaikan surat pemberitahuan yang isinya tidak benar atau tidak lengkap, merugikan keuangan negara.

Dalam pasal 39 Undang-Undang KUP termuat unsur subjektif yaitu dengan sengaja dan unsur objektifnya adalah tidak mendaftarkan diri atau tidak melaporkan usaha, menyalahgunakan NPWP, tidak menyampaikan Surat pemberitahuan, menyampaikan surat pemberitahuan yang isinya tidak benar atau tidak lengkap, menolak dilakukan pemeriksaan, tidak menyelenggarakan pembukuan di Indonesia, tidak menyimpan buku atau catatan pembukuan yang dikelola secara elektronik, tidak menyetorkan pajak, dan merugikan keuangan negara 34

Sehingga, apabila ternyata dalam proses pemeriksaan, wajib pajak tebukti telah melakukan perbuatan alpa, pelanggaran, atau kejahatan dan sanksi administrasi telah diberikan namun dianggap belum cukup maka dilakukanlah upaya terakhir dalam pemberian sanksi, yaitu dengan sanksi pidana. Proses pertama yang dilakukan terhadap tindak pidana perpajakan setelah pemeriksaan adalah penyidikan.

\footnotetext{
33 Undang-Undang Nomor 28 tahun 2007 tentang Perubahan Ketiga Atas Undang-Undang Nomor 6 Tahun 1983 Tentang Ketentuan Umum Dan Tata Cara Perpajakan Pasal 44 ayat (1).

34 Wirawan B Ilyas \& Richard Burton, Hukum Pajak, Salemba Empat, Jakarta, 2004, hlm. 73-74
} 
Pada prinsip hukum pajak, pemberian sanksi dilakukan untuk mengoptimalkan penerimaan negara dari sektor pajak. Hal ini dapat dilihat jelas dari ketentuan Pasal 44B Undang-Undang KUP yang menekankan pada aspek pembayaran uang sebagai pengganti sanksi pidana. Pasal 44B Undang-Undang KUP menyatakan bahwa untuk kepentingan penerimaan negara, atas permintaan menteri keuangan, jaksa agung dapat menghentikan penyidikan tindak pidana di bidang perpajakan paling lama dalam jangka waktu enam bulan sejak tanggal surat permintaan. Makna kata-kata "untuk kepentingan penerimaan negara" tidak dijelaskan dalam Undang-Undang, namun tidak lain dimaksudkan selain ingin menitikberatkan atau menekankan bahwa pajak bukan bertujuan memidana seseorang tetapi lebih kepada kepentingan mengumpulkan uang pajak untuk kepentingan penerimaan negara. ${ }^{35}$ Penerimaan negara dapat diartikan sebagai sejumlah uang yang patut dikumpulkan untuk kepentingan penerimaan negara. Tujuan pajak adalah mengumpulkan uang bagi kepentingan negara guna melakukan keseluruhan pembangunan di wilayah Negara Indonesia sebagaimana tujuan negara yang terdapat dalam pembukaan Undang-Undang Dasar 1945.

Selain menerapkan sanksi yang telah ditentukan Undang-Undang KUP, pemerintah dapat melakukan pendekatan alternatif yaitu melalui penjatuhan sanksi sosial. Upaya alternatif yang mungkin dapat diberikan bagi wajib pajak yang tidak memenuhi kewajiban perpajakannya adalah sanksi publikasi. Sanksi publikasi diharapkan dapat memberikan efek jera secara sosial karena masyarakat umum akan mengetahui pelanggaran atau kejahatan yang dilakukan oleh wajib pajak tersebut. Sanksi publikasi tersebut dapat diberikan sebelum diberikan sanksi pidana selama telah ada bukti bahwa wajib pajak yang bersangkutan benar-benar tidak memenuhi kewajibannya. Sebagai contoh, seperti yang dilakukan oleh Walikota Bandung, Ridwan Kamil yang menemukan situasi di Bandung sanksi sosial lebih kuat ketimbang sanksi administratif seperti denda. ${ }^{36}$ Walikota Bandung memasang spanduk besar di restoran yang tidak bayar pajak

\footnotetext{
35 Id., hlm. 61.

${ }^{36}$ Administrator, Sanksi Sosial Pajak Lebih Efektif di Kota Bandung, http://www.pikiranrakyat.com/bandung-raya/2016/11/21/sanksi-sosial-pajak-lebih-efektif-di-kota-bandung385390, (terakhir diakses 14 Oktober 2017).
} 
dan dipublikasikan ke media, besoknya restoran tersebut membayar penuh pajaknya. ${ }^{37}$

Contoh lainnya adalah Pemerintah Kota Mataram, Nusa Tenggara Barat, memperkenalkan sanksi sosial bagi penunggak pajak berupa pemasangan banner pada objek pajak yang menunggak dan ukurannya disesuaikan dengan kondisi objek pajak yang ditargetkan akan diterapkan mulai Januari 2018.38 Sanksi sosial itu bertuliskan “objek pajak ini belum melunasi kewajiban pajak daerah”. Kepala Badan Kepegawaian Daerah (BKD) Kota Mataram, HM Syakirin Hukmi, menyatakan pemasangan banner ini diharapkan dapat membuat wajib pajak merasa malu. ${ }^{39}$

Saat ini peraturan daerah tentang pemberian sanksi tersebut masih dibahas oleh anggota DPRD Mataram, sementara peraturan wali kota sedang disiapkan. ${ }^{40}$ Sebelum tahapan pemberian sanksi sosial kepada wajib pajak yang menunggak, tim penagihan BKD bersama Kejaksaan terlebih dahulu akan melakukan penagihan dan upaya persuasif. Misalnya dengan melayangkan surat tagihan dan teguran. Apabila upaya itu tidak diindahkan, BKD akan melayangkan surat pembekuan izin, dan terakhir BKD dapat meminta tim dalam hal ini Satpol PP melakukan tindakan dengan melakukan penyegelan objek pajak. ${ }^{41}$

Menurut HM Syakirin Hukmi sanksi sosial diyakini lebih efektif dibandingkan sanksi administrasi dengan pengenaan denda sebesar 2 persen per bulan dari nilai pajak. ${ }^{42}$ Dengan adanya pengumuman berukuran besar di depan objek pajak wajib pajak, wajib pajak akan merasa malu karena belum membayar kewajibannya. Sanksi sosial pemasangan papan pengumuman ini akan kita terapkan bagi semua tunggakan pajak daerah yang dikelola Kota Mataram, antara lain pajak hotel, PBB, pajak restoran, pajak parkir, pajak hiburan dan pajak

\footnotetext{
37 Id.

${ }^{38}$ Nirkomala, Pemasangan "Banner" Bentuk Sanksi Sosial Wajib Pajak, https://mataram.antaranews.com/berita/33449/pemasangan-banner-bentuk-sanksi-sosialwajib-pajak, (terakhir diakses 30 Oktober 2017).

39 Id.

40 Id.

41 Id.

42 Id.
} 
reklame. ${ }^{43}$ Khusus untuk hotel minimal terdapat tiga jenis pajak, yakni PBB, pajak hotel dan pajak restoran. Apabila salah satu jenis pajak itu belum dibayar oleh pihak hotel, tim BKD akan langsung memasang papan pengumuman di depan hotel. Hal ini tentunya dapat mengurungkan niat tamu yang akan mengingap di hotel bersangkutan. Papan pengumuman itu akan kami buka setelah pihak hotel melakukan pembayaran pajak. ${ }^{44}$

Sebagai pertimbangan lainnya, Institute for Development of Economics and Finance (INDEF) berharap Direktorat Jenderal Pajak mempublikasikan WNI yang melakukan transfer uang dari Standard Chartered Plc, Inggris ke Singapura sebesar 1,4 miliar dolar AS. ${ }^{45}$ Peneliti INDEF, Bhima Yudhistira Adhinegara mengatakan, hasil penyelidikan Dirjen Pajak pemilik dana tersebut sebagian tidak ikut program pengampunan pajak atau tax amnesty, sehingga perlu dipublikasikan ke masyarakat agar memberikan efek jera. ${ }^{46}$ Publikasi pelaku transfer dana tersebut tidak perlu dijelaskankan secara detail oleh Ditjen Pajak, tetapi hanya diungkapkan inisial saja seperti yang telah dilakukan Ditjen Pajak beberapa waktu lalu terkait delapan orang terkaya di Indonesia ada yang tidak memiliki NPWP.47 Diketahui ada 81 WNI dengan nilai kurang lebih 1,4 miliar dolar AS, 62 orang telah tax amnesty. 48

\section{Konsep Pengembalian Kerugian pada Penerimaan Negara dari Tindak Pidana Bidang Perpajakan}

Sebagaimana filosofi hukum pajak, sanksi administrasi lebih diutamakan karena pajak berhubungan langsung dengan penerimaan negara. Sanksi administrasi lebih diutamakan dikarenakan dalam kaitannya dengan peraturan dan praktik yang ditimbulkan oleh perbedaan antara hukum pidana dan hukum

\footnotetext{
43 Id.

44 Id.

45 Seno tari Sulistiyono, Transfer Dana Jumbo Ditjen Pajak Diimbau Buka Identitas Penghindar Pajak Sebagai Bentuk Sanksi Sosial, http://www.tribunnews.com/bisnis/2017/10/10/ditjenpajak-diimbau-buka-identitas-penghindar-pajak-sebagai-bentuk-sanksi-sosial, (terakhir diakses 16 Oktober 2017). 
pidana administrasi, Kongres Internasional Hukum Pidana ke-14 (XIV International Congress of Penal Law) di Vienna pada 2-7 Oktober 1989 membuat rekomendasi bahwa sanksi administrasi untuk pelanggaran pidana harus masuk akal dan proporsional dengan beratnya pelanggaran dan keadaan pribadi pelaku. Perampasan dan pembatasan kebebasan pribadi semestinya tidak diterapkan sebagai hukuman primer atau sebagai ukuran penegakan hukum. ${ }^{49}$

Berdasarkan alasan pidana administrasi, secara filosofis hukum pajak merupakan hukum publik dan penyelesaian kasus pajak diawali dengan sanksi administrasi dan sanksi non penal. ${ }^{50}$ Namun apabila sudah maksimal dan tidak berhasil, maka terhadap wajib pajak dan pihak ketiga yang terbukti melakukan tindak pidana bidang perpajakan digunakan sanksi pidana denda, yang menjunjung tinggi nilai sila kedua Pancasila "kemanusiaan yang adil dan beradab" untuk mewujudkan sila kelima Pancasila "keadilan sosial bagi seluruh rakyat Indonesia", sesuai dengan salah satu asas pemungutan pajak yaitu asas kesejahteraan. ${ }^{51}$ Asas kesejahteraan berarti bahwa dengan adanya tugas pemerintah yang pada satu pihak memberikan atau menyediakan barang-barang dan jasa bagi masyarakat dan pada lain pihak menarik pungutan-pungutan untuk membiayai kegiatan pemerintah tersebut, akan tetapi sebagai keseluruhan adalah meningkatkan kesejahteraan masyarakat. ${ }^{52}$

Pada dasarnya, pembedaan sanksi administrasi dan sanksi pidana adalah sanksi administrasi merupakan sanksi berupa pembayaran kerugian kepada negara, khususnya yang berupa bunga dan kenaikan. ${ }^{53}$ Sementara sanksi pidana merupakan siksaan atau penderitaan, merupakan suatu alat terakhir atau bentuk yang digunakan diskus agar norma perpajakan dipatuhi. Sanksi pidana terdiri dari denda pidana, pidana kurungan, dan pidana penjara. Berbeda dengan sanksi berupa denda administrasi yang hanya diancamkan atau dikenakan kepada wajib pajak yang melanggar ketentuan peraturan perpajakan, sanksi berupa denda

\footnotetext{
${ }^{49}$ Simon Nahak, Hukum Pidana Perpajakan Konsep Penal Policy Tindak Pidana Perpajakan dalam Perspektif Pembaharuan Hukum, Setara Press, Jakarta, 2014, hlm. 26.

50 Id., hlm. 10.

51 Id.

52 H. Bohari, Pengantar Hukum Pajak, PT RajaGrafindo Persada, Jakarta, 2001, hlm 43.

53 Mardiasmo, supra no. 29, hlm. 59.
} 
pidana selain dikenakan kepada wajib pajak ada juga yang diancamkan kepada pejabat pajak atau kepada pihak ketiga yang melanggar norma. ${ }^{54}$ Denda pidana dikenakan kepada tindak pidana yang bersifat pelanggaran maupun bersifat kejahatan. ${ }^{55}$

Mengenai pidana kurungan, pidana kurungan hanya diancamkan kepada tindak pidana yang bersifat pelanggaran. ${ }^{56}$ Sanksi tersebut dapat ditujukan kepada wajib pajak dan pihak ketiga. Karena pidana kurungan diancamkan kepada si pelanggar norma itu ketentuannya sama dengan yang diancamkan dengan pidana denda, maka masalahnya hanya ketentuan mengenai denda pidana sejumlah tertentu diganti dengan pidana kurungan selama-lamanya sekian. ${ }^{57}$

Pidana penjara, seperti halnya pidana kurungan, merupakan hukuman perampasan kemerdekaan. Pidana penjara diancamkan terhadap kejahatan. Ancaman pidana penjara tidak ada yang ditujukan kepada pihak ketiga, hanya kepada pejabat dan kepada wajib pajak. ${ }^{58}$

Jumlah kasus tindak pidana di bidang perpajakan yang telah selesai diselidiki oleh Direktorat Jenderal Pajak dan berkasnya dinyatakan lengkap oleh kejaksaan (P-21) antara tahun 2009 sampai tahun 2012 sebanyak 92 kasus. ${ }^{59}$ Salah satunya adalah kasus faktur pajak fiktif Asian Agri yang telah merugikan negara sebesar 1,25 triliun rupiah. Kasus ini diputus oleh Mahkamah Agung dengan putusan dua tahun penjara dengan masa percobaan satu tahun dan denda pidana lebih dari 2,5 triliun rupiah.60 Kasus lainnya adalah kasus Sulasindo Niagatama dengan total kerugian negara lebih dari 27 miliar rupiah, telah divonis pengadilan dua tahun penjara dan denda pidana sebesar 336 miliar rupiah. Kasus Sumber Tani Niaga dengan total kerugian negara hampir 77 miliar rupiah dan

\footnotetext{
${ }^{54}$ Id hlm. 60.

55 Id.

56 Id.

57 Id.

58 Id.

${ }^{59}$ Adminstrator, Tindak Pidana Perpajakan Meningkat, 92 Kasus Masuk Pengadilan, https://finance.detik.com/berita-ekonomi-bisnis/2240146/tindak-pidana-perpajakanmeningkat-92-kasus-masuk-pengadilan, (terakhir diakses 02 Juli 2017). 60 Id.
} 
telah divonis pengadilan dengan hukuman dua tahun penjara dan denda pidana sebesar lebih dari 306 miliar rupiah. ${ }^{61}$

Lebih lanjut mengenai kasus tindak pidana di bidang perpajakan, berkaitan dengan ketentuan Pasal 44B Undang-Undang KUP yaitu mengenai penghentian penyidikan tindak pidana pajak, berdasarkan data yang didapat dari Direktorat Jenderal Pajak, sepanjang tahun 2010 sampai dengan 201462 telah ada 20 orang yang telah dikabulkan permohonan penghentian penyidikannya karena menyanggupi membayar utang pajak ditambah denda sebesar empat kali utang pajak. Namun data yang diperoleh dari Kejaksaan Agung mulai tahun 2010 sampai dengan 2014 hanya sembilan orang wajib pajak yang diberikan surat ketetapan penghentian penyidikan (SKPP), dengan nilai penerimaan negara dari sektor pajak sebesar Rp. 153.159.021.925. Apabila diuraikan, maka akan diperoleh rincian sebagai berikut, yaitu pada tahun 2010 terdapat dua SKPP dengan nilai Rp. 100.977.716.815, tahun 2011 terdapat dua SKPP dengan nilai Rp. 6.251.963.250, tahun 2012 terdapat satu SKPP dengan nilai Rp. 10.921.156.805, pada tahun 2013 terdapat dua SKPP dengan nilai Rp. 25.291.741.490, dan pada tahun 2014 terdapat dua SKPP dengan nilai Rp. 9.725.443.565.63

Selisih data dari Direktorat Jenderal Pajak dengan Kejaksaan Agung adalah sebelas wajib pajak. Dari jumlah sebelas WP tersebut sebagian membatalkan permohonan atau tidak melakukan pelunasan utang pokok dan denda. ${ }^{64}$ Terhadap wajib pajak tersebut akan dilanjutkan proses penyidikan pidana. Sebagian lagi dimungkinkan dalam proses pengajuan dari Menteri Keuangan kepada Kejaksaan Agung. Diterima atau ditolaknya permohonan baik oleh Menteri Keuangan maupun penghentian penyidikan oleh Kejaksaan Agung tidak ditentukan oleh besarnya nilai nominal utang pajak, melainkan ditentukan oleh adanya itikad baik dari wajib pajak, bersifat kooperatif, adanya pengakuan kesalahan dan pelunasan utang pokok dan denda. 65

\footnotetext{
61 Id.

62 Zainal Muttaqin, dkk, supra no. 6, hlm. 9.

${ }^{63} \mathrm{Id}$.

64 Id.

65 Id.
} 
Berdasarkan data tersebut dapat diketahui bahwa pemberian sanksi administrasi berupa denda seringkali diabaikan dan pelaku lebih memilih diproses secara pidana. Mengingat filosofis tujuan hukum pajak, maka sanksi penjara akan digunakan seminimal mungkin dengan alasan tujuan hukum pajak pada prinsipnya bukan untuk mempidana wajib pajak tetapi bagaimana agar uang pajak dapat direalisasikan sebagai penerimaan negara.66 Sehingga dalam proses penjatuhan sanksi pidana tersebut pasti akan dijatuhi denda.

Apabila pada kenyataannya lebih banyak wajib pajak yang menjadi tersangka tindak pidana perpajakan dan lebih memilih sanksi pidana tersebut bukannya tanpa alasan. Hal tersebut berkaitan dengan pasal 30 ayat (2) dan ayat (3) Kitab Undang-Undang Hukum Pidana (selanjutnya disebut KUHP) yang menyatakan bahwa jika denda tidak dibayar, maka diganti dengan kurungan. Lamanya kurungan tesebut paling singkat 1 hari dan paling lama 6 bulan sebagaimana diatur dalam KUHP. Hal ini sejalan dengan yang diuraikan sebelumnya. Sehingga efektifitas dalam proses penerimaan negara pun kembali dipertanyakan.

Sebagaimana diketahui, bahwa pemungutan pajak memiliki dua fungsi utama, yaitu fungsi budgeter dan fungsi regulern. Sebagaimana telah diuraikan sebelumnya, penerimaan pajak menjadi sumber penerimaan negara yang paling besar, sehingga dapat dikatakan bahwa fungsi budgeter saat ini lebih diutamakan, meskipun bukan berarti fungsi regulern diabaikan. Fungsi budgeter artinya pajak merupakan instrumen untuk memasukan dana dari masyarakat secara optimal ke dalam kas negara berdasarkan undang-undang perpajakan yang berlaku. ${ }^{67}$ Optimal dalam hal ini dapat ditafsirkan sebagai upaya mengumpulkan pajak itu sendiri tanpa melewatkan berbagai sumber-sumbernya, dan dalam hal ini mengutamakan pemberian sanksi administrasi bagi wajib pajak dan pihak ketiga yang tidak memenuhi kewajiban perpajakannya, serta pemberian sanksi pidana merupakan upaya untuk mengoptimalkan penerimaan negara. Sebagaimana

\footnotetext{
${ }^{66}$ Rochim, supra no. 16, hlm. 24.

${ }^{67}$ Sony Devano dan Siti Kurnia Rahayu, Perpajakan, Konsep, Teori, dan Isu, Kencana Prenada Media Group, Jakarta, 2006, hlm. 21.
} 
sanksi pidana, menurut Mardiasmo, merupakan sanksi yang berupa siksaan atau penderitaan, yang merupakan suatu alat terakhir yang digunakan pemerintah agar norma perpajakan dipatuhi. 68

Demikian halnya mengacu pada substansi dan penjelasan umum UndangUndang KUP, maka penggunaan sanksi pidana kurungan dan penjara adalah sebagai sanksi subsider atau sebagai ultimum remedium. Uraian Undang-Undang KUP lebih mendahulukan sanksi pidana denda dan upaya non penal. Sanksi pidana kurungan dan pidana penjara diberlakukan apabila pidana denda dan upaya non penal itu tidak berhasil.

Tujuan utama dari Undang-Undang KUP sebagaimana terdapat dalam konsiderans ditentukan bahwa dalam rangka menghadapi dampak krisis keuangan global, sangat mendesak untuk memperkuat basis perpajakan nasional guna mendukung penerimaan negara dari sektor perpajakan yang lebih stabil, maka diketahui tujuan Undang-Undang KUP adalah untuk kepentingan penerimaan keuangan negara, maka tindak pidana bidang pajak lebih mengutamakan konsep pengembalian kerugian negara daripada penjatuhan sanksi pidana kurungan dan penjara untuk diterapkan terhadap pelaku tindak pidana perpajakan oleh wajib pajak dan pihak ketiga di Indonesia.

Gagasan untuk memperbaharui pemberian sanksi terhadap pelaku tindak pidana pajak sebenarnya sudah banyak yang mengusulkan. Seperti, misalnya untuk pidana denda, porsinya diperbanyak serta diutamakan sebagai sanksi utama, sebelum pidana kurungan dan pidana penjara agar mendorong sebesarbesarnya penerimaan negara. ${ }^{69}$ Memperbanyak sanksi denda baik secara administrasi maupun sanksi pidana dapat saja dilakukan, namun peningkatan sanksi denda dalam sanksi administrasi terhadap wajib pajak yang tidak memenuhi kewajiban perpajakannya dapat menyebabkan wajib pajak tersebut tetap tidak memenuhi kewajibannya dan tidak menjalankan sanksi sehingga dapat berakibat meningkatnya jumlah pelaku tindak pidana dan lebih memilih sanksi

68 Mardiasmo, Perpajakan Edisi Revisi, Penerbit Andi, Yogyakarta, 2011, hlm. 59-60.

${ }^{69}$ Simon Nahak, supra no. 36, hlm. 20. 
pidana yang merupakan upaya terakhir (ultimum remedium) dengan ancaman sanksi penjara dan denda pidana.

Kemudian lebih jauh lagi, sanksi penjara juga tidak akan membuat negara mendapatkan pemasukan yang seharusnya dibayarkan oleh wajib pajak, tapi justru menambah kewajiban negara untuk menyediakan penjara yang layak dan penambahan pengeluaran untuk membiayai narapidana. Demikian halnya dengan ancaman sanksi denda pidana, berapapun jumlah atau besarnya denda pidana akan tetap dapat diganti dengan kurungan minimal 1 hari dan maksimal 6 bulan apabila terdakwa tidak mampu membayar denda pidana tersebut. ${ }^{70}$ Kondisi demikian tidak akan membuat filosofi tujuan hukum pajak tercapai, yaitu mengoptimalkan penerimaan negara, karena setelah kurungan sebagai pengganti denda pidana selesai maka pelaku tindak pidana pajak telah hilang kewajiban membayar utang pajaknya.

Hal tersebut sejalan dengan pernyataan Philipus M. Hadjon, sebagaimana dikutip Simon Nahak, menyatakan bahwa negara akan rugi jika wajib pajak dipidanakan, karena tujuan Undang-Undang KUP adalah pendapatan negara sebesar-besarnya.71 Tindakan penegakan hukum pajak harus mendahulukan sanksi administrasi, sedangkan sanksi pidana bersifat ultimum remedium. Sanksi pidana dikenakan jika sanksi administrasi sudah maksimal, untuk itu jika ada pelanggaran pajak seharusnya dikenakan sanksi administrasi lebih dahulu untuk memperoleh pendapatan negara sebanyak-banyaknya. ${ }^{72}$

Atas dasar mengoptimalkan penerimaan negara juga diatur mengenai kebijakan non penal terhadap upaya penanggulangan pelaku tindak pidana di bidang perpajakan sebelum dilakukan kebijakan penal. Kebijakan ini terdapat dalam Pasal 44B Undang-Undang KUP, yang mengatur mengenai penghentian tindak pidana pajak sepajang perkara tersebut belum dilimpahkan ke pengadilan. Terdapat argumentasi hukum mengenai penanggulangan melalui cara non penal berupa mediasi penal terhadap pelaku tindak pidana yang dikemukakan oleh

\footnotetext{
${ }^{70}$ Kitab Undang Undang Hukum Pidana Pasal 30 ayat (2) dan ayat (3).

${ }^{71}$ Simon Nahak, supra no. 36, hlm. 220.

72 Id.
} 
Barda Nawawi Arief, yang menyatakan bahwa perkembangan dan latar belakang munculnya ide mediasi penal sebagai pilihan penyelesaian perkara pidana yang terintegrasi dalam sistem peradilan pidana. Perkembangan tersebut dapat dilihat salah satunya dari hasil Kongres PBB ke-9 tahun 1995 yang merilis dokumen penunjang yang berkaitan dengan manajemen peradilan pidana yang mengungkapkan perlunya semua negara mempertimbangkan mediasi, konsolidasi, restitusi, dan konpensasi dalam sistem peradilan pidana. ${ }^{73}$

Berdasarkan uraian di atas, maka dapat diajukan rumusan kembali mengenai besaran sanksi denda dalam Undang-Undang KUP. Ancaman sanksi denda administrasi tidak perlu ditambahkan besarannya mengingat kemungkinan akan lebih banyak wajib pajak yang memilih menjalankan sanksi pidana dibandingkan sanksi administrasi sebagaimana telah diuraikan sebelumnya. Yang harus dirumuskan adalah ketentuan mengenai sanksi pidana. Sanksi pidana dalam ketentuan Undang-Undang KUP saat ini terdiri dari ancaman sanksi penjara dan sanksi denda pidana. Untuk itu, pidana denda harus diutamakan, sehingga rumusannya adalah sanksi pidana denda lalu sanksi penjara, bukanlah sanksi penjara lalu sanksi pidana denda. Sanksi pidana denda didahulukan atau diutamakan dibandingkan sanksi penjara bagi wajib pajak pelaku tindak pidana mengingat tujuan hukum pajak untuk mengoptimalkan penerimaan negara dan bukan membatasai atau merampas kemerdekaan seseorang. Selain itu, jumlah sanksi pidana denda diperbesar agar menimbulkan efek jera terhadap pelaku. Besarnya pidana denda dapat dirumuskan minimal empat kali utang pajak, yaitu menyesuaikan dengan jumlah sanksi administrasi yang harus dibayarkan oleh wajib pajak apabila mengajukan penghentian penyidikan tindak pidana di bidang perpajakan sebagaimana tercantum dalam ketentuan Pasal 44B Undang-Undang KUP. Hal ini dilakukan untuk meminimalisir jumlah wajib pajak yang ingin melakukan penyelesaian tindak pidana di bidang perpajakan melalui jalur penal.

\footnotetext{
73 Barda Nawawi Arief, Mediasi Penal: Penyelesaian Perkara Pidana di Luar Pengadilan, http://berdanawawi.wordpress.com/2009/12/27/mediasi-penal-penyelesaian-perkara-di-luarpengadilan/2009 (terakhir diakses 3 November 2017).
} 


\section{Penutup}

Filosofi tujuan dari hukum pajak bermuara pada penerimaan pajak. Hal tersebut sejalan dengan salah satu fungsi dari hukum pajak, yaitu fungsi budgeter yang berorientasi pada pajak yang merupakan sumber utama dalam optimalisasi penerimaan negara. Berkaitan dengan penerimaan negara tersebut, secara empiris bentuk penerimaan negara yang diperoleh dari pajak bukanlah hanya dari jumlah utang pajak yang dimiliki oleh wajib pajak kepada negara, namun juga berasal dari sanksi yang diberikan sebagai implikasi dari tidak dipenuhinya kewajiban membayar pajak tersebut.

Sebagaimana diketahui bahwasanya sanksi dalam hukum pajak yang terdapat dalam Undang-Undang KUP berupa sanksi administrasi dan sanksi pidana. Pemberian sanksi tersebut diberikan kepada wajib pajak yang telah dikategorikan sebagai pelaku tindak pidana perpajakan. Sanksi yang diberikan untuk pertama kali adalah sanksi administrasi, untuk kemudian ketika sanksi administrasi tersebut tidak mau atau tidak mampu dilakukan oleh wajib pajak, maka masuklah proses pidana sebagai upaya pemberian sanksi terakhir (ultimum remedium).

Pemberian sanksi pidana yang pada dasarnya adalah pemberian nestapa atau penderitaan terhadap pelaku tindak pidana tidak sejalan dengan filosofi hukum pajak yang berorientasi pada pengoptimalan penerimaan negara. Sehingga Penulis memberi gagasan untuk membuat pembaharuan regulasi, berupa penambahan nominal sanksi pidana denda sebesar minimal empat kali dari utang pajak dan pengutamaan sanksi pidana denda dalam proses pemberian sanksi pidana.

\section{Daftar Pustaka}

\section{Buku:}

Bohari, Pengantar Singkat Hukum Pajak, PT. Rajawali Persada, Jakarta, 1995.

Dewi Kania Sugiharti, Perkembangan Peradilan Pajak di Indonesia, Refika Aditama, Bandung, 2005. 
G.A. Jacobsen dan M.H. Lipman, Political Science, College Outline Series, Barnes \& Noble Inc, New York, 1960.

H. Bohari, Pengantar Hukum Pajak, PT RajaGrafindo Persada, Jakarta, 2001.

Mardiasmo, Perpajakan Edisi Revisi, Penerbit Andi, Yogyakarta, 2011.

Rochim, Modus Operandi Tindak Pidana Pajak, Solusi Publishing, Jakarta, 2010.

Rochmat Soemitro, Asas dan Dasar Perpajakan, PT Eresco, Bandung, 1993.

Hukum Pajak Internasional Indonesia Perkembangan dan

Pengaruhnya, Eresco, Bandung, 1977. Pengantar Singkat Hukum Pajak, Eresco, Bandung, 1992.

Santoso Brotodihardjo, Pengantar Ilmu Hukum Pajak, Refika Aditama, Bandung, 1998.

Simon Nahak, Hukum Pidana Perpajakan Konsep Penal Policy Tindak Pidana Perpajakan dalam Perspektif Pembaharuan Hukum, Setara Press, Jakarta, 2014.

Sony Devano dan Siti Kurnia Rahayu, Perpajakan, Konsep, Teori, dan Isu, Kencana Prenada Media Group, Jakarta, 2006.

Syofrin Syofyan dan Asyhar Hidayat, Hukum Pajak dan Permasalahannya, Refika Aditama, Bandung, 2004.

Wirawan B. Ilyas dan Richard Burton, Manajemen Sengketa dalam Pemungutan Pajak Analisis Yuridis Terhadap Teori dan Kasus, Mitra Wacana Media, Jakarta, 2012.

2004.

Hukum Pajak, Salemba Empat, Jakarta,

Jurnal:

Zainal Muttaqin, dkk, Penegakan Hukum di Bidang Perpajakan Melalui Mekanisme Diluar Pengadilan (Suatu Alternatif), Jurnal Mimbar Hukum Universitas Gadjah Mada Vol. 27 No. 2, 2 (Juni 2015).

\section{Pustaka yang Tidak Dipublikasi}

Dadang Yusuf Juhaeni, Pengaturan Pemungutan dan Pengawasan Pajak Pada Transaksi Melalui Elektronic Commerce (E-Commerce) Guna Meningkatkan Penerimaan Negara, Tesis Magister Kenotariatan Pascasarjana Universitas Padjadjaran, Bandung, 2011

Dewi Kania Sugiharti, Prospek Pengaturan Insentif dan Disinsentif Pajak berkaitan dengan Penerapan Prinsip Pencemar Membayar Sebagai Perwujudan Sistem Hukum Nasional, Disertasi, Fakultas Hukum Universitas Padjadjaran, Bandung, 2010

\section{Web Dokumen}

Adminstrator, Tindak Pidana Perpajakan Meningkat, 92 Kasus Masuk Pengadilan, https://finance.detik.com/berita-ekonomi-bisnis/2240146/tindak-pidanaperpajakan-meningkat-92-kasus-masuk-pengadilan, (terakhir diakses 02 Juli 2017). 
Administrator, Belajar Pajak, www.pajak.go.id, (terakhir diakses 29 Oktober 2012).

Admistrator, Apa Itu Tax Ratio?, https://solusibisnis.co.id/apa-itu-tax-ratio-rasiopajak.html (terakhir diakses 10 Oktober 2017).

Administrator, Sanksi Sosial Pajak Lebih Efektif di Kota Bandung, http://www.pikiran-rakyat.com/bandung-raya/2016/11/21/sanksisosial-pajak-lebih-efektif-di-kota-bandung-385390, (terakhir diakses 14 Oktober 2017).

Barda Nawawi Arief, Mediasi Penal: Penyelesaian Perkara Pidana di Luar Pengadilan, http://berdanawawi.wordpress.com/2009/12/27/mediasipenal-penyelesaian-perkara-di-luar-pengadilan/2009 (terakhir diakses 3 November 2017).

Direktorat Penyusunan APBN, Direktorat Jenderal Anggaran, Informasi APBN 2016, https://www.kemenkeu.go.id/sites/default/files/bibfinal.pdf (terakhir diakses 1 September 2017).

Direktorat Jenderal Pajak, Laporan Kinerja Direktorat Jenderal Pajak 2016, http://www.pajak.go.id/sites/default/files/LAKIN\%20DJP\%202016.pdf (terakhir diakses 7 Agustus 2017).

Gito Adiputo Wiratno, Sri Mulyani: Tax Ratio Indonesia Terendah, https://www.wartaekonomi.co.id/read126937/sri-mulyani-tax-ratioindonesia-terendah.html (terakhir diakses 3 November 2017).

Nirkomala, Pemasangan "Banner" Bentuk Sanksi Sosial Wajib Pajak, https://mataram.antaranews.com/berita/33449/pemasangan-bannerbentuk-sanksi-sosial-wajib-pajak, (terakhir diakses 30 Oktober 2017).

Safyra Primadhyta, Wajib Pajak Yang Lapor SPT Tembus 9,01 Juta Orang, https://www.cnnindonesia.com/ekonomi/20170402035743-78204324/wajib-pajak-yang-lapor-spt-tembus-9-juta-orang/ (terakhir diakses 17 Agustus 2017).

Seno tari Sulistiyono, Transfer Dana Jumbo Ditjen Pajak Diimbau Buka Identitas Penghindar Pajak Sebagai Bentuk Sanksi Sosial, http://www.tribunnews.com/bisnis/2017/10/10/ditjen-pajak-diimbaubuka-identitas-penghindar-pajak-sebagai-bentuk-sanksi-sosial, (terakhir diakses 16 Oktober 2017).

\section{Peraturan Perundang-Undangan}

Undang-Undang Dasar Negara Republik Indonesia Tahun 1945.

Kitab Undang-Undang Hukum Pidana.

Kitab Undang-Undang Hukum Acara Pidana.

Undang-Undang Nomor 28 tahun 2007 tentang Perubahan Ketiga Atas UndangUndang Nomor 6 Tahun 1983 Tentang Ketentuan Umum Dan Tata Cara Perpajakan.

Undang-Undang Nomor 25 tahun 2007 tentang Penanaman Modal. 


\section{Wawancara}

Hasil wawancara dengan Eri Dripa, Kepala Kantor Pajak Pratama Kramat Jati, Jalan Dewi Sartika Nomor 189 A, Jakarta Timur, pada Jumat, 11 April 2014, jam $09.00-10.30$. 